\title{
Effects of nutrient enrichment in the nation's estuaries: A decade of change
}

\author{
S.B. Bricker ${ }^{\mathrm{a}, *}$, B. Longstaff ${ }^{\mathrm{b}}$, W. Dennison ${ }^{\mathrm{c}}$, A. Jones ${ }^{\mathrm{c}}$, K. Boicourt $^{\mathrm{b}}$, C. Wicks $^{\mathrm{b}}$, J. Woerner $^{\mathrm{c}}$ \\ a NOAA National Centers for Coastal Ocean Science, 1305 East West Highway, Floor 9, Silver Spring, MD 20910, United States \\ ${ }^{\mathrm{b}}$ EcoCheck, NOAA Chesapeake Bay Office \& University of Maryland Center for Environmental Science, Cooperative Oxford Laboratory, \\ 904 South Morris Street, Oxford, MD 21654, United States \\ ${ }^{\mathrm{c}}$ University of Maryland Center for Environmental Science, PO Box 775, Cambridge, MD 21613, United States
}

\section{A R T I C L E I N F O}

\section{Article history:}

Received 11 September 2007

Received in revised form 20 June 2008

Accepted 1 August 2008

\section{Keywords:}

Algae

Dissolved oxygen

Eutrophication

Nitrogen

HABs

Nutrients

Submerged aquatic vegetation

\begin{abstract}
A B S T R A C T
An updated assessment of nutrient related impacts in US estuaries was completed in 2007. This assessment evaluates three components for each estuary: the influencing factors (e.g. land use, nutrient loads), the overall eutrophic condition (e.g. chlorophyll $a$, presence of nuisance/toxic algae and macroalgae, extent of dissolved oxygen problems, loss of submerged aquatic vegetation), and future outlook. Eutrophication is a widespread problem with $65 \%$ of assessed systems showing moderate to high level problems. The most impacted region was the mid-Atlantic. The majority of estuaries assessed, with the exception of North Atlantic systems (Cape Cod north to Maine), are highly influenced by human related activities that contribute to land-based nutrient loads. Conditions were predicted to worsen in $65 \%$ and to improve in $19 \%$ of the assessed estuaries in the future. Analysis of the extent of change from the early 1990 s to the early 2000 s, for those systems for which sufficient data were available, shows that conditions mostly remained the same (32 of 58 systems) though changes were observed in several smaller systems; 13 systems improved and 13 systems worsened. Chlorophyll $a$ and HAB impacts have increased in the mid-Atlantic region, the only region with data adequate for comparison. These symptoms are more prevalent in systems with longer residence times, such as coastal lagoons. The successful restoration of seagrass in Tampa Bay is encouraging though future management to sustain the recovery will be difficult given expected population increases. This national assessment illustrates the need for coordinated and integrated action that balances management action, efficient monitoring to assess the effectiveness of the management, focused research, and a communication campaign aimed at engaging the broader community.
\end{abstract}

(c) 2008 Elsevier B.V. All rights reserved.

\section{Introduction}

Nutrient additions to estuaries and coastal water bodies occur naturally as a result of geological weathering and inputs from ocean upwelling. However, in recent decades population growth and related nutrient sources such as agriculture, wastewater treatment plants, urban runoff, and consumption of fossil fuels (atmospheric deposition), have increased nutrient inputs to many times their natural levels to the point that eutrophication is now regarded as one of the greatest threats to coastal ecosystem health (CENR, 2000; NRC, 2000). Nutrient additions cause a progression of eutrophic symptoms that most often begin with observations of high concentrations of chlorophyll $a$ and/or macroalgal blooms (Fig. 1a). Excessive algal blooms may lead to other more serious impacts including loss of submerged aquatic vegetation (SAV) and

\footnotetext{
* Corresponding author. Tel.: +1 301713 3020x139; fax: +1 3017134388 .

E-mail address: suzanne.bricker@noaa.gov (S.B. Bricker).
}

a shift from benthic to pelagic dominated system productivity (Bowen and Valiela, 2001), low dissolved oxygen and occurrences of nuisance/toxic blooms or HABs (Bricker et al., 1999, 2007). While all symptoms do not occur in all systems, there are commonalities among the impacts observed, and the sequence of impacts. Among other impacts, eutrophic symptoms can threaten both abundance and diversity of fish and other biota (Bowen and Valiela, 2001; Breitburg, 2002; Wazniak and Glibert, 2004), and may lead to impairments to aesthetics, fishing opportunities and success (Lipton and Hicks, 1999, 2003; Bricker et al., 2006), tourism, and real estate value (Hoagland et al., 2002).

In the 1990s, the National Oceanic and Atmospheric Administration (NOAA) began to evaluate the need for a more deliberate National response to the problem of estuarine eutrophication given the concern of the scientific community and the public about the nutrient related health of US coastal water bodies. The National Estuarine Eutrophication Assessment, a survey of the extent, severity, types, and probable causes of eutrophic symptoms, was conducted in the early 1990s (Bricker et al., 1999). The results showed that the 
(a) Impact: No Problem /low Moderate low Moderate Moderate high

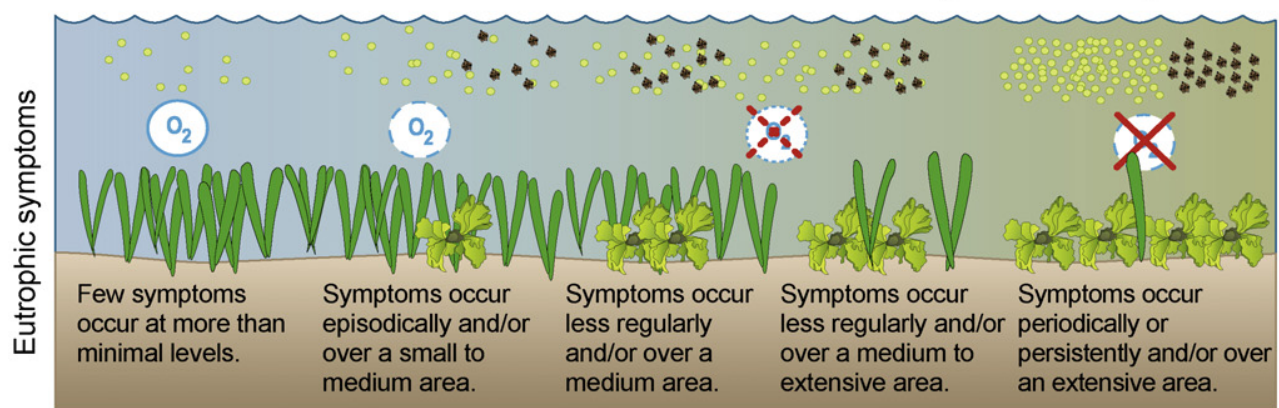

Key to symbols:

Submerged aquatic vegetation

Chlorophyll a

Nuisance/toxic blooms (HAB)

Macroalgae

Dissolved oxygen

(b)

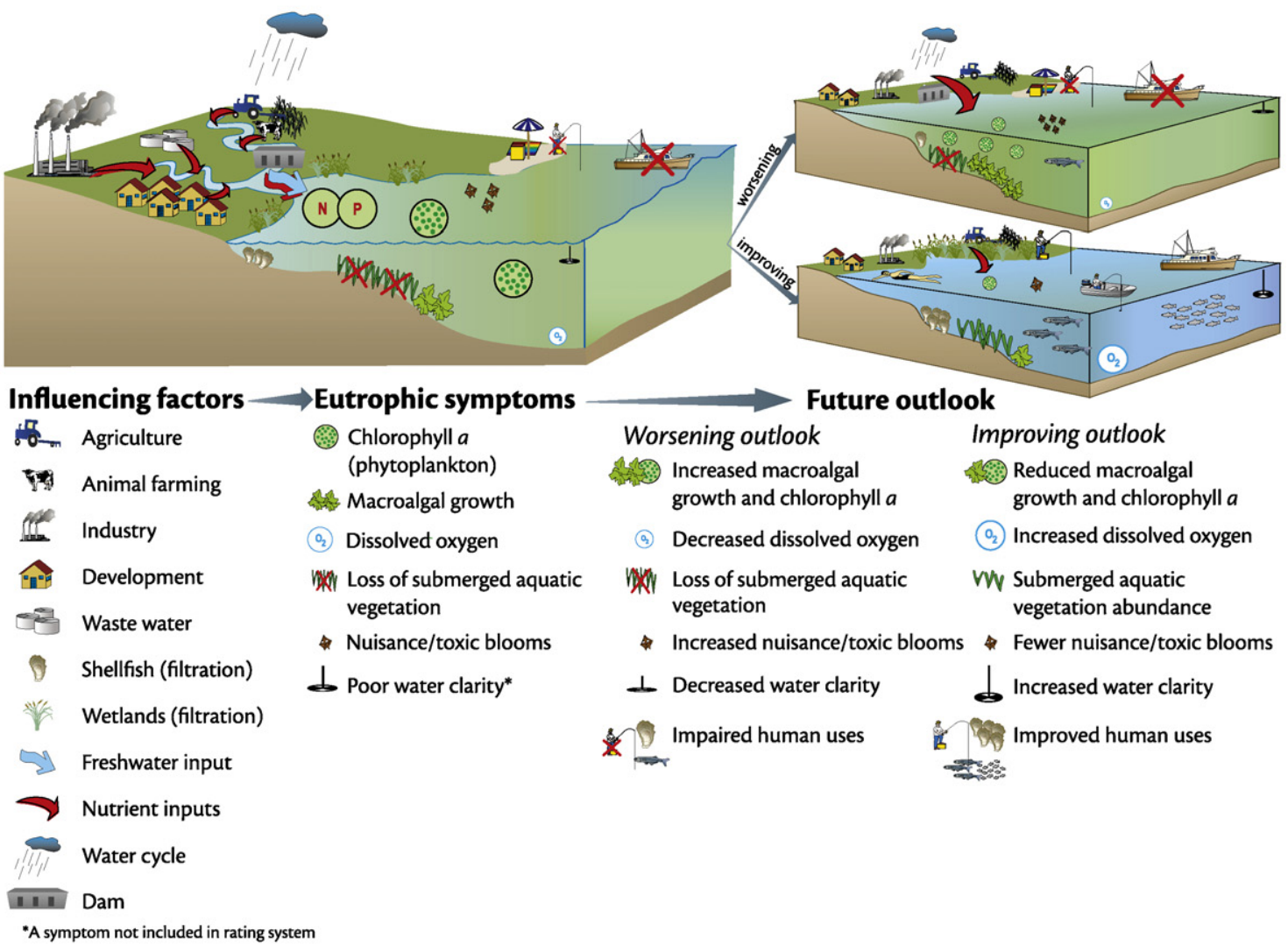

Fig. 1. (a) A conceptualization of the relationship between overall eutrophic condition, associated eutrophic symptoms and influencing factors (nitrogen load and susceptibility), and (b) the NEEA update evaluates influencing factors, eutrophic symptoms and future outlook for 141 US estuarine and coastal water bodies (adapted from Bricker et al., 2007).

majority of systems included in the study (84 of 139) exhibited 'moderate' to 'high' levels of eutrophic symptoms that occurred along all coastlines. Most of these systems also showed impairment of everyday uses including warnings against swimming and consumption of fish due to lower abundance or quality. The report suggested that conditions in more than half of the estuaries were expected to become worse by the year 2020 due to high-density populations and significant population increases currently occurring or expected in coastal areas. The poor prognosis for the health of the Nation's estuaries suggested that regular updates were needed to assess and track changes in the health of these systems and to evaluate the success of management strategies.

This paper describes an update to the 1999 assessment (Bricker et al., 2007) that examines conditions in the early 2000s, and the changes that have occurred since the early 1990s, the timeframe of the 1999 report. One of the main aims of these assessments is to provide the basis for development of a national strategy to limit nutrient enrichment problems affecting US estuarine and coastal water bodies (Bricker et al., 1999, 2007). The 2007 assessment provides context for recent and planned activities designed to address these issues, such as the Harmful Algal Bloom and Hypoxia Research and Control Act of 1998 (reauthorized in 2004; P.L. 105383), the multi-agency National Coastal Condition report (USEPA, 2005), and the Gulf of Mexico Alliance Governors' Action Plan. It should be noted, however, that these problems are not limited to US coastal waters. These problems are global in scope and have led to legislative actions elsewhere, such as the European Union Water Framework Directive, Urban Waste Water Treatment Directive, 
and Nitrates Directive and the People's Republic of China Law on Prevention and Control of Water Pollution. The comparison of eutrophication impacts and successful management measures in US and international coastal water bodies highlights the knowledge that with effort, these problems can be reversed. This paper focuses on the main results of the 2007 National Estuarine Eutrophication Assessment report; additional results are included in the full report (http://www.noaanews.noaa.gov/stories2007/ s2898.htm). This assessment method is now available as a desktop program at http://www.eutro.org/register.

Recent attention has been focused on the contribution of eutrophication to the proliferation and increase in some $\mathrm{HAB}$ species (e.g. Anderson et al., 2002; Glibert et al., 2005b; Heisler et al., 2008). High biomass blooms, as indicated by increases in chlorophyll a can cause smothering of submerged aquatic vegetation and corals (e.g. Tampa and Sarasota Bays; Greening and Janicki, 2006; Tomasko et al., 1996) and is used in the National Estuarine Eutrophication Assessment as an indication of nutrient related problems. HABs are considered an indication of a more developed nutrient problem. For this assessment, both non-toxic forms that at high concentration can cause hypoxia and anoxia and losses of filter feeders due to poor nutritional quality and the small size clogging siphons (e.g. the brown tide organism Aureoccocus anophagefferens, Wazniak and Glibert, 2004), as well as those that produce neurotoxins and can cause illness and death due to these toxins (Glibert et al., 2005a) are considered. Because of the variability in threshold concentration of bloom organisms that cause toxicity and other problems, the assessment method defines these blooms as a problem if they cause "a detrimental impact to any biological resource” (Bricker et al., 1999, 2003, 2007).

Given the number of systems included in these assessments (141 estuaries), the data from the two assessments (Bricker et al., $1999,2007)$ provide an opportunity to examine whether there has been a change from the early 1990s to the early 2000s. Additionally, the data provide an opportunity to examine the relationship between overall eutrophication impacts and the occurrence of HABs. Also of interest is the relationship between HABs and physical and hydrologic conditions. These analyses provide an opportunity to make conclusions about these relationships that may provide insight to possible management strategies to reduce the impact of these blooms. In some places, however, these symptoms might not respond to management and instead must be "managed" by, for example, interdiction of shellfish harvest to protect the population from illness.

\section{Study area}

The assessment focused on 141 estuaries and coastal water bodies along all US coastlines that together represent greater than $90 \%$ of the total freshwater flow into US coastal areas, and cover an equal water body surface area. Two systems, representing an addition of $6 \mathrm{~km}^{2}$, were added to the 2007 assessment that were not included in the 1999 assessment. The systems were divided into 5 regions; the North Atlantic includes systems from Maine to Cape Cod, the Mid-Atlantic includes systems from Cape Cod to Chesapeake Bay, the South Atlantic includes systems from North Carolina to Florida, the Gulf of Mexico includes systems from Florida to Texas and the Pacific Coast region includes systems from California to Washington.

The 141 systems are highly diverse with regard to physical and hydrologic characteristics (e.g. landscape elevation and climate), watershed population and land use. These characteristics strongly influence the potential for development of eutrophic symptoms. For example, headwaters of Atlantic coast estuaries mostly originate from the Appalachian Mountains, a relatively low-lying range along the eastern US shoreline. In the north, they are relatively close to the coast, leading to short and steep watersheds of higher elevation. In the south, the range is farther inland, leading to longer and flatter watersheds of lower elevation (typically half that of northern watersheds; Table 1). Estuary type also changes from river mouth estuaries in the north to lagoon systems in the south. Headwaters of Pacific Coast estuaries also originate in the mountains, but from a diversity of ranges including the Rocky Mountains, Coastal Range, and Sierra Nevada. North Pacific systems have the highest watershed elevations of any region and, while most Gulf of Mexico watersheds are low-lying, some in the west extend into the Sierra Nevada, giving them higher mean elevations.

Estuary size varies nationally and regionally. The mid-Atlantic region, for example, includes the large Chesapeake Bay and much smaller coastal lagoon systems. The Gulf of Mexico region includes the massive Mississippi River basin as well as the small coastal watersheds of Florida. The ratio of watershed area to estuarine area may exert a significant influence on the development of

Table 1

Summary of physical characteristics and population density for each region and within regions. ${ }^{\text {a }}$

\begin{tabular}{|c|c|c|c|c|c|c|c|c|c|}
\hline Region & $\begin{array}{l}\text { Mean } \\
\text { estuarine } \\
\text { area }\left(\mathrm{km}^{2}\right)\end{array}$ & $\begin{array}{l}\text { Mean } \\
\text { depth } \\
(\mathrm{m})\end{array}$ & $\begin{array}{l}\text { Tidal } \\
\text { range } \\
(\mathrm{m})\end{array}$ & $\begin{array}{l}\text { Mean } \\
\text { watershed } \\
\text { area }\left(\mathrm{km}^{2}\right)\end{array}$ & $\begin{array}{l}\text { Mean } \\
\text { water shed } \\
\text { elevation }(\mathrm{m})\end{array}$ & $\begin{array}{l}\text { Mean } \\
\text { annual } \\
\text { precipitation } \\
(\mathrm{m})\end{array}$ & $\begin{array}{l}\text { Average } \\
\text { annual } \\
\text { temperature } \\
\left({ }^{\circ} \mathrm{C}\right)\end{array}$ & $\begin{array}{l}\text { Average } \\
\text { frost } \\
\text { days } \\
\text { (days) }\end{array}$ & $\begin{array}{l}\text { Water shed } \\
\text { population } \\
\text { density } \\
\left(\text { people } \mathrm{km}^{-2} \text { ) }\right.\end{array}$ \\
\hline North Atlantic & 264 & 12.9 & 2.8 & 4284 & 100 & 1.2 & 8 & 156 & 65 \\
\hline Mid-Atlantic & 923 & 4.7 & 0.80 & 13,521 & 116 & 1.1 & 13 & 106 & 156 \\
\hline Estuaries & 1140 & 5.7 & 0.86 & 17,137 & 147 & - & - & - & - \\
\hline Lagoons & 189 & 1.4 & 0.59 & 1,232 & 13 & - & - & - & - \\
\hline South Atlantic & 534 & 2.9 & 1.2 & 15,043 & 58 & 1.3 & 19 & 36 & 52 \\
\hline $\mathrm{NC}$ to $\mathrm{GA}$ & 522 & 3.2 & 1.3 & 15,678 & 66 & 1.3 & 19 & 41 & 43 \\
\hline Florida & 761 & 1.4 & 0.48 & 11,018 & 9 & 1.3 & 23 & 5 & 129 \\
\hline Gulf of Mexico & 822 & 1.7 & 0.41 & 109,545 & 107 & 1.3 & 22 & 12 & 30 \\
\hline FL MS LA AL & 882 & 1.8 & 0.47 & 133,068 & 73 & 1.5 & 22 & 13 & 28 \\
\hline $\mathrm{TX}$ & 667 & 1.6 & 0.26 & 46,031 & 198 & 0.98 & 22 & 9 & 32 \\
\hline Pacific & 182 & 14 & 1.5 & 25,209 & 401 & 1.1 & 12 & 57 & 33 \\
\hline Fjord (WA) & 438 & 66 & 2.4 & 5,822 & 477 & 1.1 & 10 & 73 & 91 \\
\hline River mouth (OR) & 133 & 6.9 & 1.4 & 42,039 & 459 & 1.7 & 12 & 66 & 10 \\
\hline Lagoons (S. CA) & 75 & 3.5 & 1.1 & 1,297 & 271 & 0.29 & 16 & 23 & 320 \\
\hline
\end{tabular}

a Data source: S.V. Smith (2003).

b Does not include Mississippi River to avoid biasing results due to extreme watershed size. 
eutrophication, especially in areas of dense watershed population. This ratio can be used as an indicator of the influence of watershedbased inputs on the estuary.

Climate also varies among the regions. The driest watersheds are located in the southern Pacific Coast and western Gulf of Mexico regions (Table 1). Land cover in these areas is mostly grassland, shrub land, and savanna. Rainfall along the north and mid-Atlantic and Pacific coasts is higher, with land cover in these regions mostly deciduous and evergreen forests. South Atlantic and eastern Gulf of Mexico systems have a subtropical climate, with higher annual rainfall and land cover dominated by crop land and woodland. Climate along the coast is modulated by ocean temperatures, which are much warmer on average along the Gulf of Mexico and South Atlantic regions than along the Pacific Coast and North Atlantic regions. The number of frost days mirrors regional temperature differences; with 156 frost days per year in the North Atlantic region, 57 per year in the Pacific Coast region and 12 frost days per year in the Gulf of Mexico region (Table 1).

The other factor that influences the development of eutrophic symptoms is the nutrient load to these systems. Population density can be used as a relative indicator of pressure since most land-based sources are human related. Population densities vary among regions and sub-regions with highest densities observed in the mid-Atlantic region and Southern California, and lowest densities in the Gulf of Mexico region and Oregon (Table 1). Although both phosphorus and nitrogen can cause nutrient enrichment problems in estuaries, only nitrogen inputs were included in the assessment because nitrogen is typically the limiting nutrient in estuaries and coastal water bodies. With some exceptions (i.e. San Francisco Bay North, Mississippi River, Southern California) nitrogen loads mirrored population densities, highest loads were observed in the mid-Atlantic region (Fig. 2). In the Gulf of Mexico region, high loads corresponded with high agricultural activity and the Mississippi River outflow. Analysis of loads was performed using a model that compares nutrient loads from the watershed to loads from the ocean in order to identify whether the loading source is primarily the watershed and is related to human activities, or is from ocean inputs (Bricker et al., 2003;
Ferreira et al., 2007). Nutrient loads are derived mainly from the watershed in more than $75 \%$ of systems.

\section{Assessment method}

The National Estuarine Eutrophication Assessment method and modifications, called Assessment of Estuarine Trophic Status (hereafter called NEEA) have been well described in Bricker et al. (1999, 2003, 2007), Ferreira et al. (2007) and Scavia and Bricker (2006). A comparison of this approach with that of other assessment methods can be found in Bricker et al. (2006) and Xiao et al. (2007). The NEEA assessment method evaluates eutrophication by examining influencing factors, overall eutrophic condition and future outlook, and the results are then combined into a single overall rating. A completeness and reliability of the overall eutrophic condition assessment is based on the temporal and spatial availability of data. In this way, an assessment can be made with minimal data that provides some insight to the condition within the system.

\subsection{Influencing factors}

Influencing factors help establish a link between a system's natural sensitivity, or susceptibility, to eutrophication as a result of flushing and dilution characteristics, and the nutrient loading and eutrophic symptoms that are observed. In most cases, if the water (and therefore nutrients) is flushed quickly, there is insufficient time for eutrophic symptoms to develop (i.e. low susceptibility). However, if the estuary has a long residence time, there is time for nutrients to be taken up by algae and for blooms to develop. Physical and hydrologic data are used separately to define dilution and flushing ratings which are combined by a matrix to give a susceptibility rating. The susceptibility rating is combined in a matrix with a rating for nitrogen loads to determine the final influencing factor rating. The load component is estimated as the ratio of nitrogen coming from the land (i.e. human-related) to that coming from the ocean (Bricker et al., 2003; Ferreira et al., 2007).

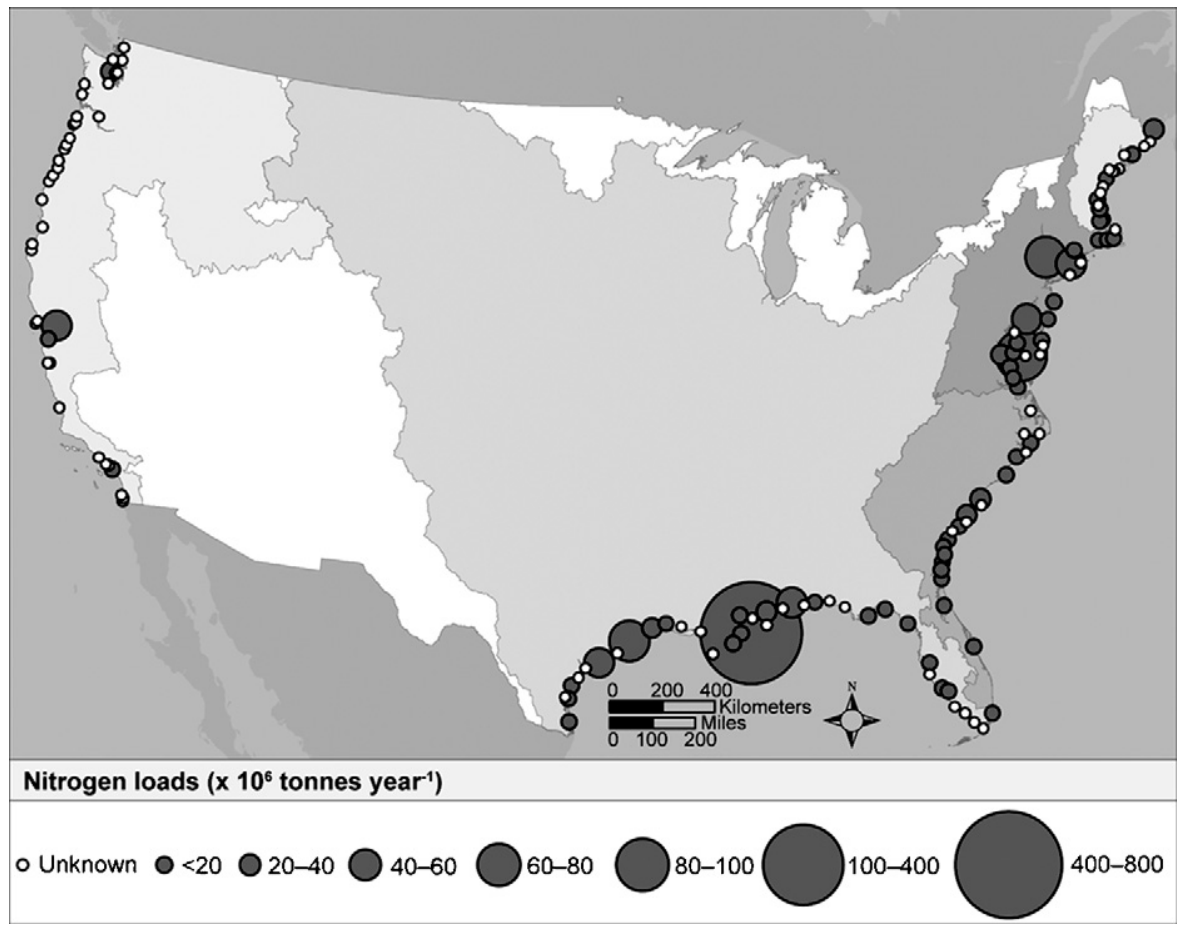

Fig. 2. Nitrogen load to coastal water bodies in the US (data from: Castro et al., 2001 and Bricker et al., 2007). 
The load rating also provides insight into load management since loads that are primarily oceanic in origin will not be easily controlled. In addition to evaluating influencing factors, susceptibility can be used to forecast what symptoms may potentially occur. For example, in some shallow lagoon systems, additional nutrients may result in increased macroalgal abundance rather than high concentrations of phytoplankton/chlorophyll $a$ (Nobre et al., 2005). A typology of these systems is being developed in order to increase assessment and forecasting accuracy by accounting for differences in how systems respond to nutrient inputs (Bricker et al., 2007).

\subsection{Overall eutrophic condition}

Assessment of the overall eutrophic condition is based on assessment of five symptoms. For each symptom, a level of expression is determined by evaluating the occurrence, spatial coverage and frequency of the symptom. Chlorophyll $a$ and macroalgae are considered primary symptoms that, at high levels, indicate the first stage of water quality degradation associated with eutrophication. The three secondary symptoms represent more serious impacts: low dissolved oxygen levels, loss of submerged aquatic vegetation, and occurrences of HABs. The average of the primary symptoms and the worst case of the secondary symptoms (a precautionary approach) are combined by a matrix to determine the overall eutrophic condition rating.

In many estuaries, primary symptoms lead to more serious secondary symptoms. In some cases secondary symptoms can exist in the estuary without originating from primary symptoms. This occurs in many North Atlantic estuaries where some HABs may be transported into the system from the coastal ocean (Bricker et al., 2006). Such systems were consequently given a lower rating (i.e. indicating lesser impact) for HABs than those systems for which these blooms originated within the system. Low ratings, rather than a designation of no problem, were used because it is unclear whether offshore HABs grow and are maintained by landbased nutrient sources once they enter the system.

It should be noted that nutrient concentrations are not used as an indicator because they reflect the net biological, physical, and chemical processes such that even a severely degraded system may exhibit low concentrations due to uptake by phytoplankton and macroalgae. Conversely a relatively healthy system might have high concentrations due to low algal uptake, strong filter feeder populations, or may flush nutrients so quickly that phytoplankton do not have the opportunity to bloom extensively.

\subsection{Future outlook}

Future outlook in this assessment is a prediction of what eutrophic conditions will be in the year 2020, based on expected changes in nutrient loads and the estuary's susceptibility to these loads. This assessment component combines the susceptibility of a system and the predicted future nutrient loads to determine whether conditions will worsen, improve or remain the same. Recommendations for potential management responses to eutrophication were developed from conclusions based on the evaluation of future outlook (Bricker et al., 2007).

\subsection{Synthesis: assessment of estuarine trophic status}

In an effort to simplify the comparison of the eutrophication status among systems, the last step in the assessment procedure is to combine the influencing factor, overall eutrophic condition, and future outlook components into a single overall score for each system. The ratings for influencing factors, overall eutrophic condition, and future outlook are combined in a matrix to provide an overall grade or score which may fall into one of five categories: high, good, moderate, poor, or bad. These categories provide a scale for setting reference conditions for different types of systems (Bricker et al., 2003). A 'high' grade will not be assigned if the expected future outlook is for worsening conditions, but a system may be rated as 'good' based on high or good overall eutrophic condition and influencing factors, even if the expectation is that it will worsen in the future. Ratings of 'poor' reflect a range of undesirable pressure and state conditions, even if there are management plans for recovery.

\section{Results and discussion}

\subsection{Influencing factors}

The majority of systems assessed (36 of 64; the balance of the 141 systems had inadequate data for this analysis) had 'high' influencing factor ratings, indicating that these estuaries receive a large amount of nitrogen from human related activities compared to their capacity to dilute or flush nutrients (Fig. 3). High nitrogen loads were largely attributed to the influence of expanding and dense coastal human populations. Influencing factor ratings were 'high' from New York to Texas, 'low' in the North Atlantic, and mostly 'unknown' in the Pacific region. 'Low' influencing factors in the North Atlantic region are likely due to relatively low nitrogen loads and strong tidal flushing. In contrast, 'high' ratings in the mid-Atlantic region likely result from high nitrogen loads relative to susceptibility. The high geographic variability of nitrogen loading and susceptibility indicates a need for locally tailored management action.

\subsection{Overall eutrophic condition}

The majority of estuaries assessed (64 of 99 systems; 42 systems had inadequate data for this analysis) had eutrophic conditions rated as 'moderate' to 'high'. These systems represent $78 \%$ of the assessed estuarine surface area. The overall eutrophic condition and symptom expressions were geographically variable though systems with high ratings are mainly located in the midAtlantic region (Fig. 4). In fact, the largest concentration of highly eutrophic systems is located around Chesapeake Bay, an area that also had 'high' influencing factor ratings and the highest population density of any region. There were 35 systems (21\% of assessed surface area) which exhibited 'low' to 'moderate low' overall eutrophic conditions. More than half of these estuaries were located in the Gulf of Mexico and Pacific Coast regions. In some cases, estuaries in close proximity to each other exhibited very different overall eutrophic condition. The most commonly occurring eutrophic symptom was high frequency of elevated chlorophyll $a$ levels (Fig. 5a). Most estuaries also exhibited at least one other moderate to high symptom expression in addition to chlorophyll a (e.g. HABs; Fig. 5b).

The most frequently noted causes of eutrophic impairments were agricultural activities (crops and animal operations), urban runoff, wastewater treatment plants (though an improvement over septic tanks, the waste treatment process does not remove $100 \%$ of nutrients thus wastewater treatment plants discharge nutrients), and atmospheric deposition. These are the major sources of nutrients that were included in the total loads used to determine influencing factors. Several patterns emerged with respect to influencing factors and eutrophic conditions. Of the 15 estuaries with a 'high' overall eutrophic condition, 13 also had 'high' susceptibility scores. In contrast, of the 35 systems with 'moderate low' or 'low' overall eutrophic condition, 31 had 'low' or 'moderate' 


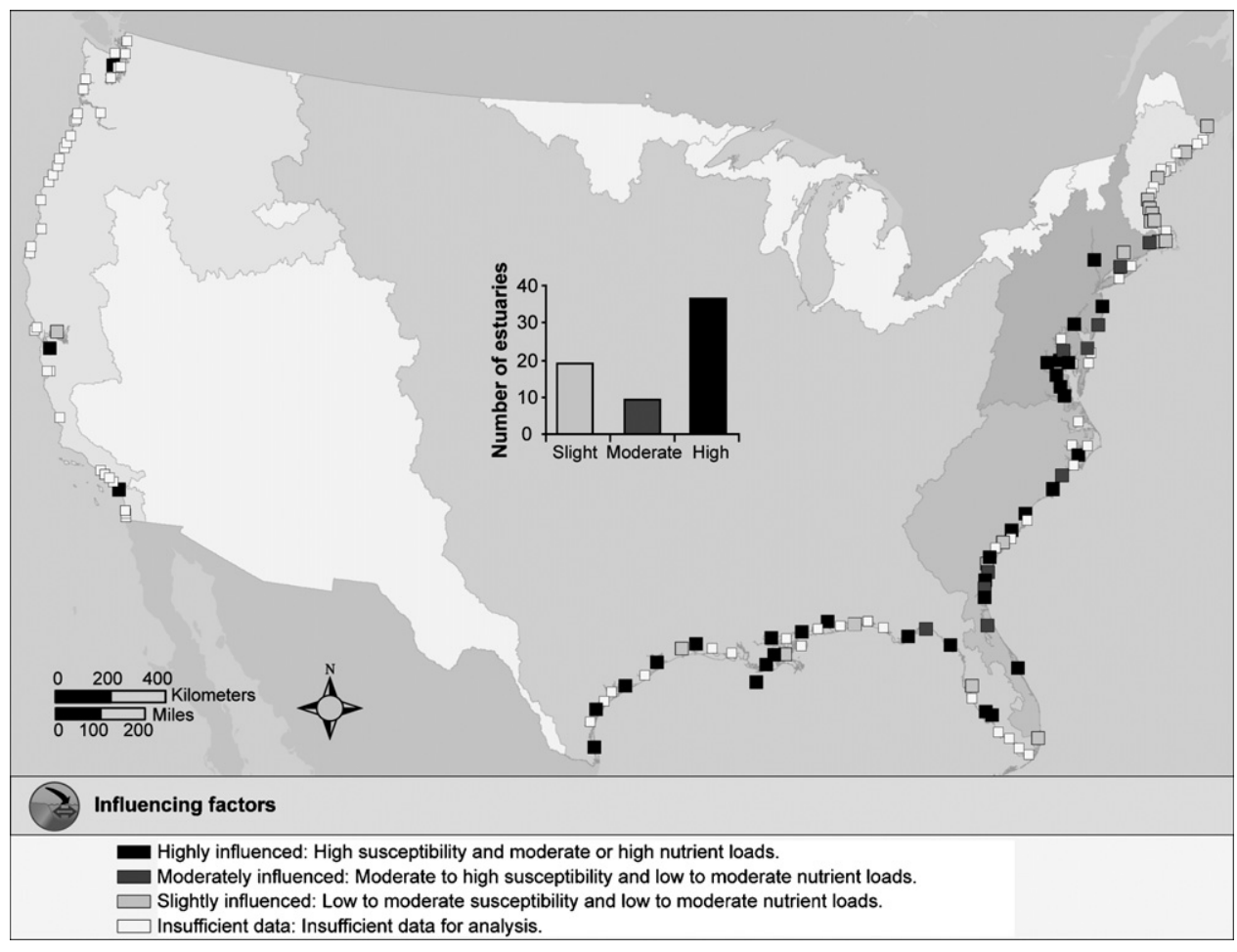

Fig. 3. Influencing factors of eutrophication on a national scale (from Bricker et al., 2007).

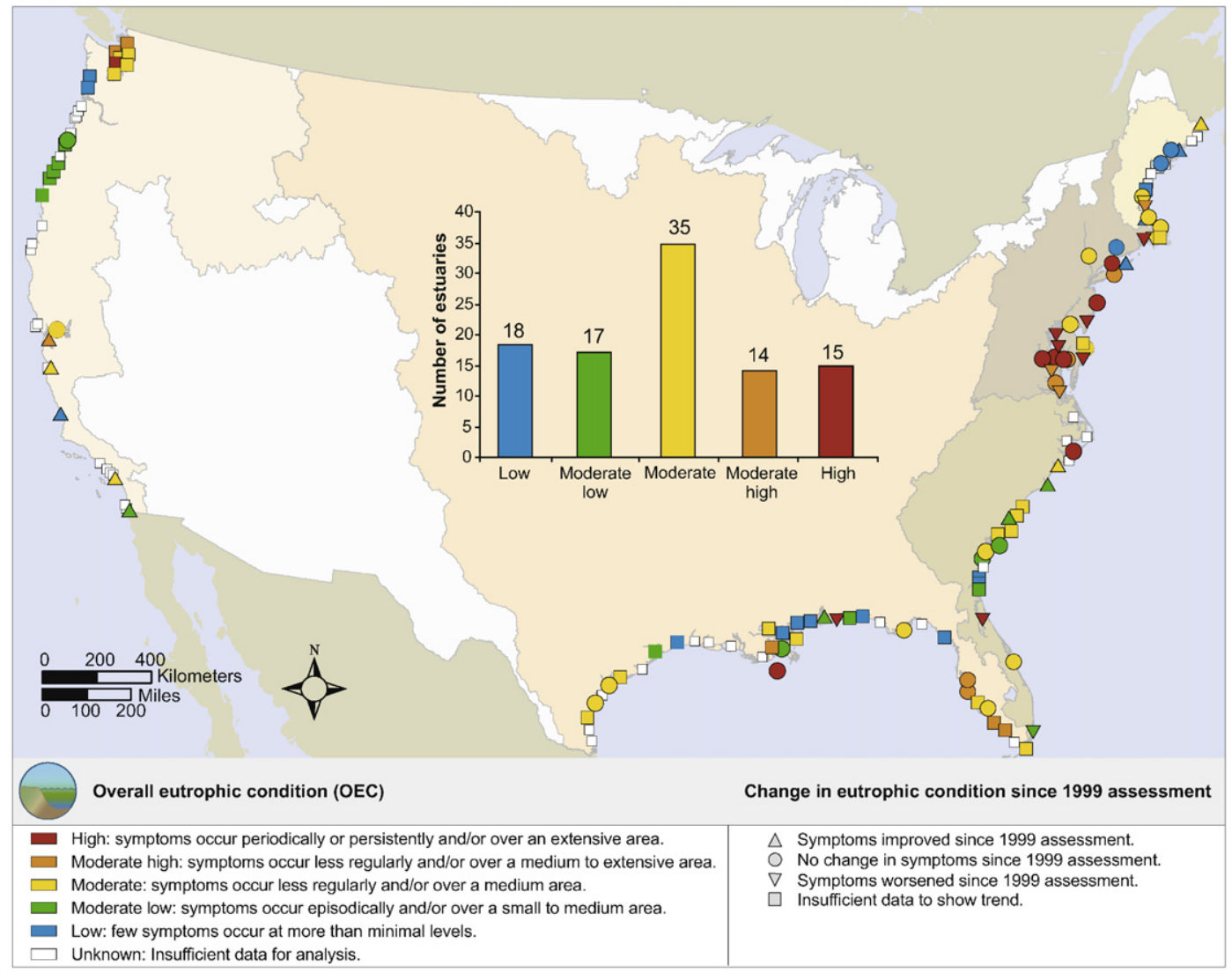

Fig. 4. Overall eutrophic condition on a national scale (from Bricker et al., 2007). 
(a)

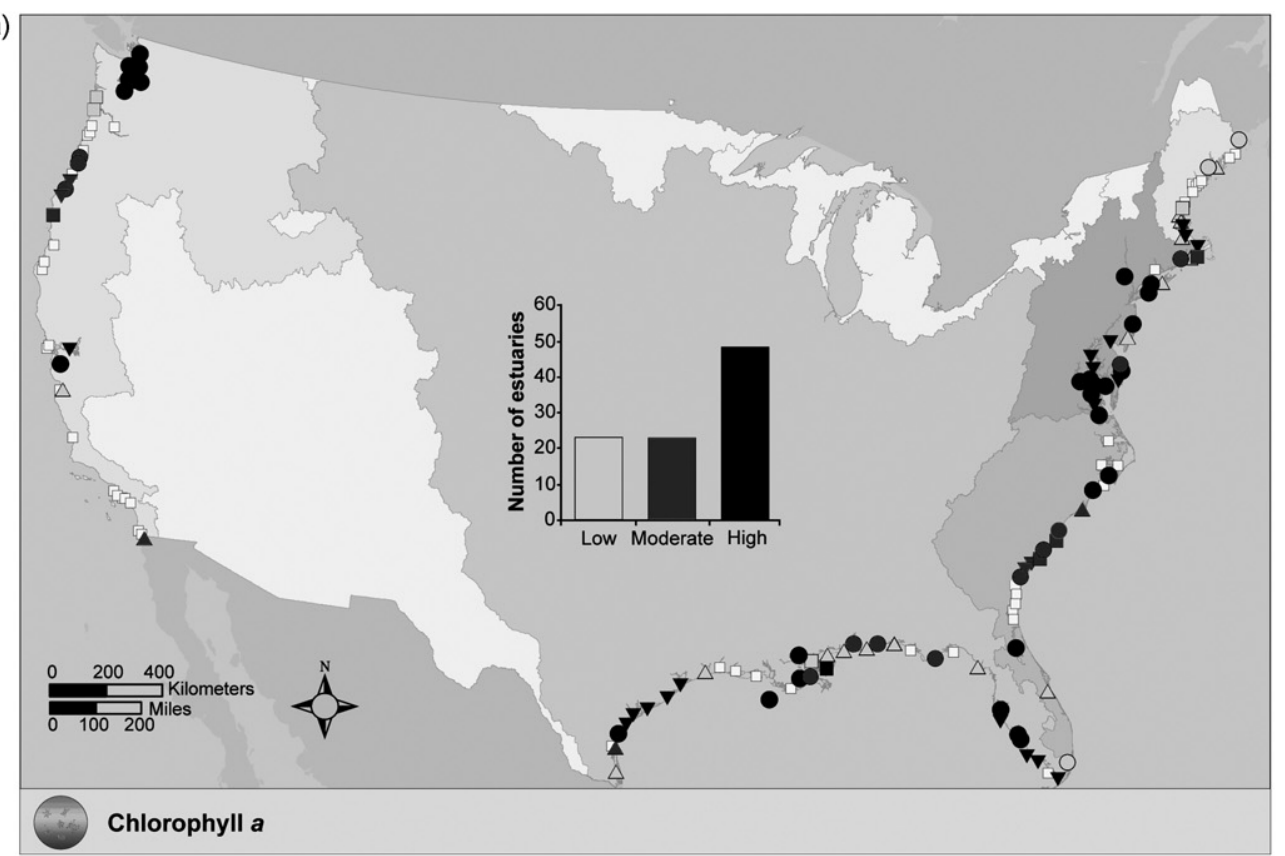

(b)

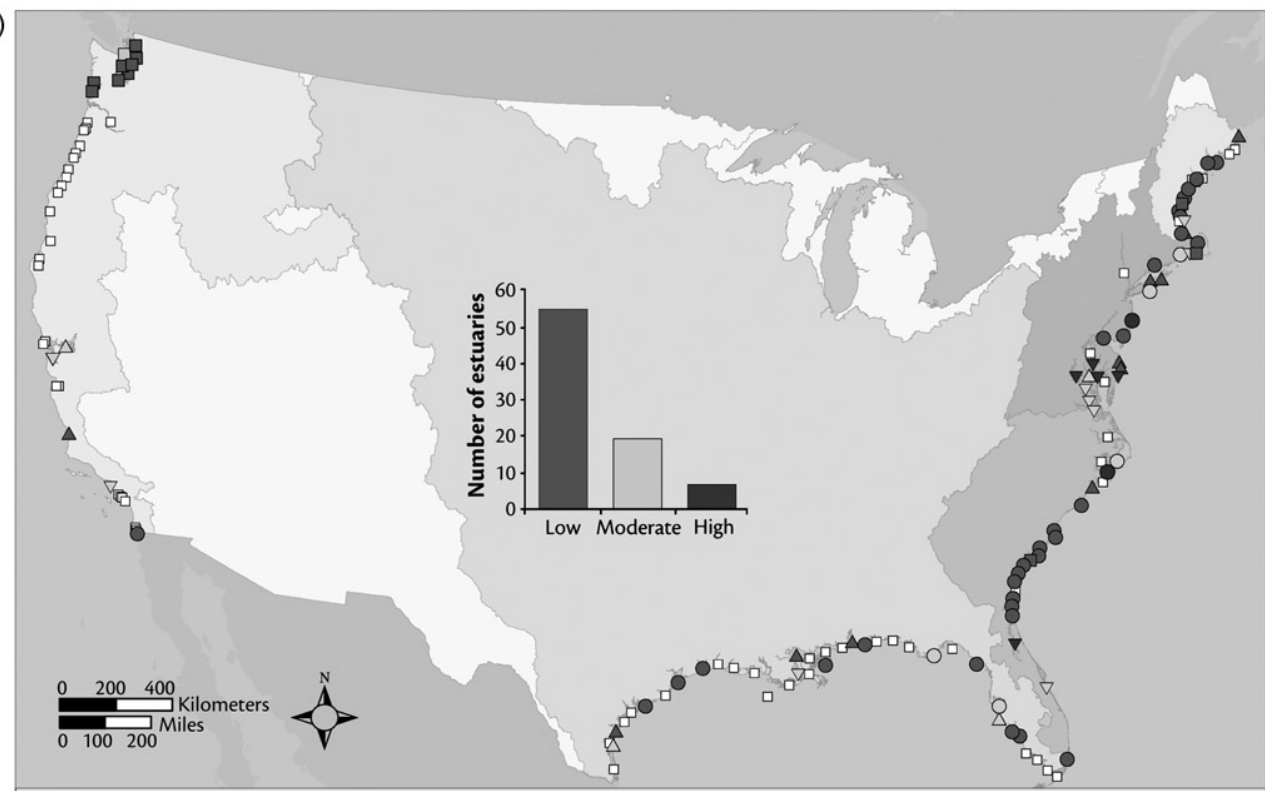

d) Nuisance/toxic blooms

\begin{tabular}{l|l}
\multicolumn{1}{c|}{ Symptom Expression } & Change since 1999 assessment \\
\hline $\begin{array}{l}\text { High: symptoms generally occur periodically or persistently } \\
\text { and/or over an extensive area. }\end{array}$ & $\triangle$ Symptoms improved since 1999 assessment. \\
$\square \begin{array}{l}\text { Moderate: symptoms generally occur less regularly and/or over a } \\
\text { medium area. }\end{array}$ & $\bigcirc$ No change in symptoms since 1999 assessment. \\
$\begin{array}{l}\text { Low: few symptoms occur at more than minimal levels. } \\
\text { Unknown: Insufficient data for analysis. }\end{array}$ & $\nabla$ Symptoms worsened since 1999 assessment. \\
NH Not historically observed. & $\square$ Insufficient data to show trend. \\
\hline
\end{tabular}

Fig. 5. Symptom expressions on a national scale for (a) chlorophyll $a$ and (b) Nuisance/toxic blooms (HABs; from Bricker et al., 2007).

susceptibility. Eleven of these 31 systems had a 'low' or 'moderate low' overall rating despite high nutrient loads. These systems seem able to naturally suppress eutrophication.

Data confidence and reliability varied among systems. The general trend was for at least moderate data confidence and reliability in systems with 'high' overall eutrophic conditions but low data confidence and reliability for systems with 'moderate' or 'low' overall eutrophic ratings. Most of the systems with high confidence are located in the North and mid-Atlantic regions, while those with low confidence are located in the Gulf of Mexico and Pacific Coast regions.

\subsection{Changes in eutrophic condition since the 1990s}

Comparison of eutrophic conditions assessed from the early 1990 s to early 2000s indicates largely similar levels of eutrophica- 


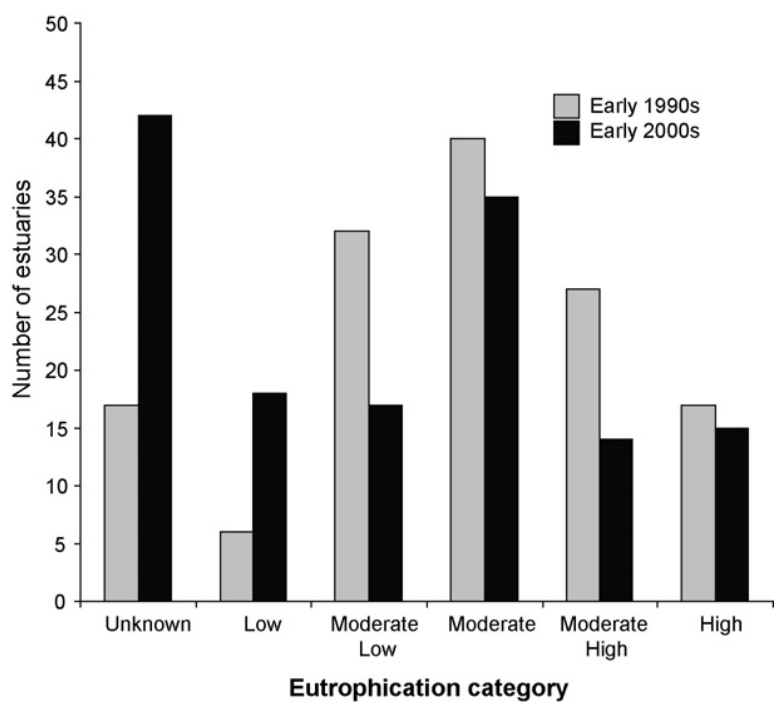

Fig. 6. Number of estuaries in each eutrophication category in the early 1990s (1999 assessment; Bricker et al., 1999) and early 2000s (Bricker et al., 2007).

tion (Fig. 6) despite average population increases in coastal counties of 13\% between 1990 and 2003 (Crossett et al., 2004). Among the systems where data were available for comparison (58), conditions in 32 had remained the same (77\% assessed surface area) while conditions in 13 systems had improved (9\% of assessed surface area), and in another 13 systems conditions had worsened (14\% assessed surface area). In the early 1990s, $69 \%$ of assessed systems (72\% of assessed area) had moderate to high eutrophic conditions compared to $65 \%$ of assessed systems (78\% of assessed area) in the early 2000s (Fig. 6). However, these results must be viewed with caution, because the total number of systems for which conditions are unknown has increased from 17 in the 1999 assessment to 42 in this assessment. This is likely due to a change in data collection methods; the 1999 assessment involved site visits and regional and national workshops, while the 2007 study involved self-reporting of data via an online survey and a national workshop. Similar to the early 1990s, the Pacific Coast region had the least robust data and the lowest assessment confidence.

\subsection{Future outlook}

Worsening conditions by 2020 were predicted for 65\% of estuaries and improvements predicted for $20 \%$ of estuaries for which the analysis was performed (Fig. 7). This is largely based on population estimates which, on a national basis, suggest that coastal populations, already $53 \%$ of the total, will continue to increase by about $12 \%$ over the same time frame (Crossett et al., 2004). Future outlook was not determined for 67 systems, illustrating uncertainty in the future outlook conclusions. There are presently 12 systems with a 'moderate low' to 'low' overall eutrophic condition but 'moderate' to 'high' susceptibility and a 'worsening' future outlook. Although many systems are predicted to worsen as population in the coastal zone increases, the systems with 'low' eutrophic conditions and 'moderate' to 'high' susceptibility should be a priority for protective management because they are the most at risk. The

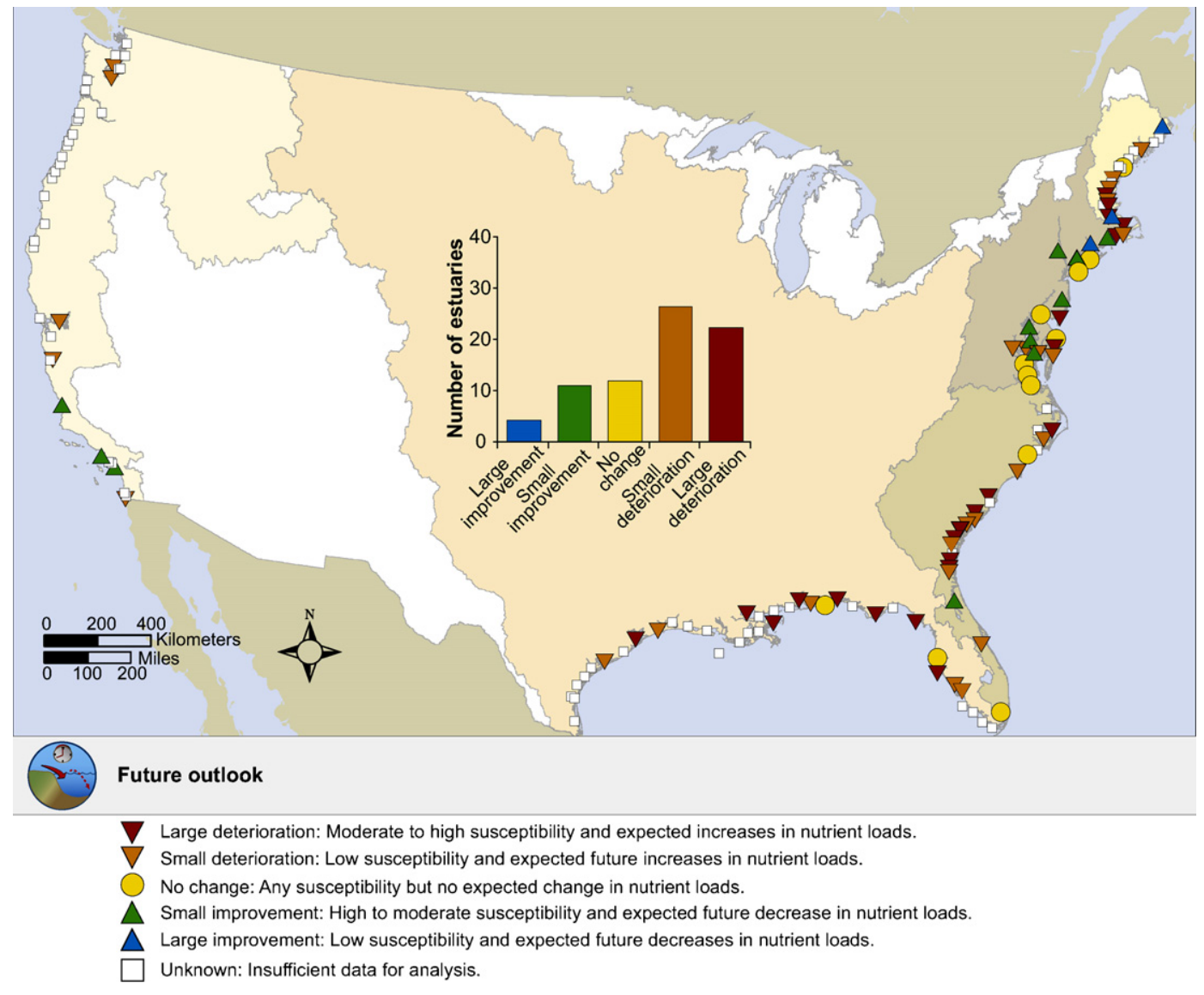

Fig. 7. Future outlook on eutrophic condition on a national basis (from Bricker et al., 2007). 
potential for changes in nutrient loads and hydrology due to climate change should also be explored when considering future estuarine health.

\subsection{Synthesis: assessment of estuarine trophic status}

Only 48 systems had data for all three components and only these could be assigned a synthesis rating. Of these, only one was rated as 'high' water quality and 24 were rated as 'poor' or 'bad'.

\subsection{Residence time and development of HABs}

It is clear from the results of this study and others that landbased sources of nutrients are a significant factor influencing the development of nutrient related water quality problems. However, it is also known that the susceptibility, largely determined by the residence time of water within a system, also plays a significant role. Ferreira et al. (2005) used a screening model with data from several Portuguese systems and the 139 US systems from Bricker et al. (1999) to show that residence time influences the development of HABs and the number and diversity of phytoplankton species that occur in an estuary. Put simply, the model examines the average production day $^{-1}(P)$ required for a phytoplankton species to be present in an estuary and the maximum production day $^{-1}\left(P_{\max }\right)$ which would result in a bloom, and compares those to residence time of the study systems. In this way it is possible to predict whether blooms may occur. Many dinoflagellates, including those that are toxic, have maximum growth rates that are substantially lower than those of most diatoms, which typically are not toxic (Furnas, 1990; Smayda, 1997) and thus may have a greater tendency to bloom in systems with slower residence times. Not surprisingly, the Ferreira et al. (2005) analysis showed higher ratings, i.e. greater concentrations, spatial coverage and frequency of occurrence, of high chlorophyll $a$ levels and HAB problems in systems of slower flushing or longer residence time.
The data from the 1999 and 2007 assessments provides the opportunity to examine in more detail the role of hydrologic conditions in the potential development of blooms. Here, the recent data from Bricker et al. (2007) are used to analyze the relationship between residence time and eutrophication assessment results in the same fashion as done previously in Ferreira et al. (2005). This analysis includes ratings for chlorophyll $a$, HABs and, though it is partially derived from the other two, the overall eutrophic condition ratings. The systems used for the analysis are the same as those used in the previous study and the residence times used here are the same as those used in Ferreira et al. (2005). Fig. 8a-c shows the results of the analysis using the more recent assessment data. It is clear that with slower residence times, more significant problems are observed. For HABs, 'high' ratings (i.e. worse conditions) are seen only in the slowest residence time systems (Fig. 8a). Likewise, 'high' (i.e. worst) overall eutrophic conditions are only observed in the systems with the slowest residence times (Fig. 8c). While these results do not incorporate nutrient pressures, they should serve to reinforce that the systems that presently do not show eutrophic symptoms but are highly susceptible (i.e. long residence times) and have expectations for watershed population increases should be made a priority for protection. Additionally, these results may provide insight to the development of blooms during periods of different flow conditions. For example, during drought periods more blooms might be expected to occur since residence times slow down (e.g. as per very slow residence time systems in Fig. 8a and b). This may have contributed to an episodic outbreak of Pfiesteria sp. in Chesapeake Bay in the 1990s (Magnien, 2001). This capability to predict potential blooms may be helpful in development of management responses. In cases of toxic bloom organisms it may be that interdiction of shellfish collection to protect populations from harm is the only "management" possible. However, in engineered systems, it may be possible to increase flow to mitigate a developing bloom or prevent $\mathrm{HAB}$ conditions from occurring altogether.
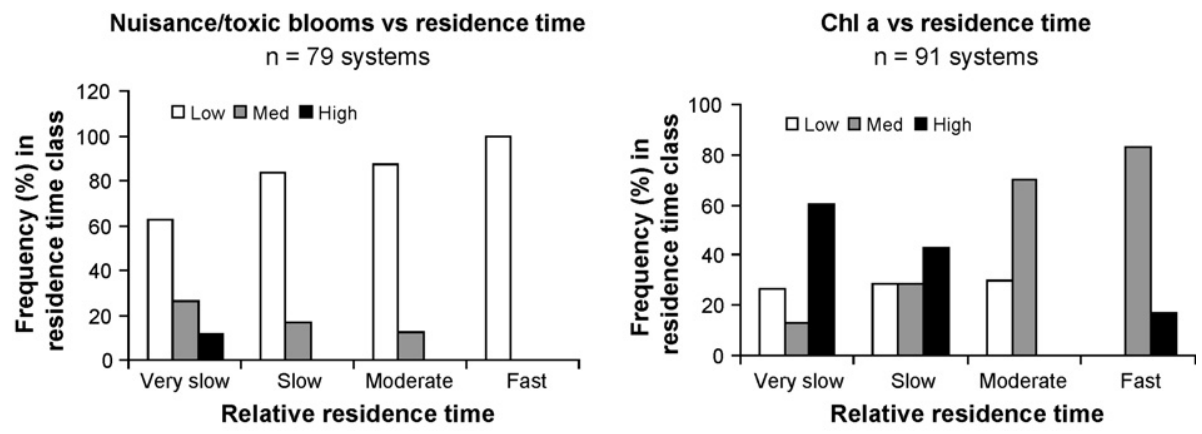

Overall Eutrophic Condition vs residence time

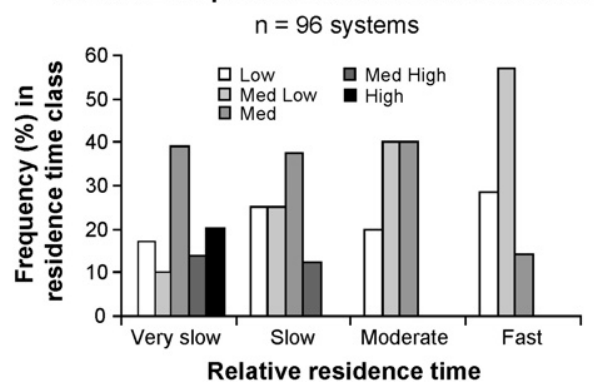

Fig. 8. Frequency distribution of NEEA scores for eutrophication symptoms (a) nuisance and toxic blooms, (b) chlorophyll $a$ (high chlorophyll $a$ in the fast residence time system group represents one system, Brazos River), and (c) overall eutrophic condition for 141 US estuaries within each residence time class (very slow residence time is $<1.5$ $P_{\max }$ per method of Ferreira et al., 2005). 


\subsection{Case studies: overall eutrophication, chlorophyll a and HABs}

Case studies provide the basis for sharing successful management approaches that may be used both in the US and abroad. Two case studies are presented here, the first includes lagoon systems in the mid-Atlantic region, longer residence time systems where HABs are observed. The other case study for Tampa Bay highlights that it is not only HAB organisms that are a problem, non-toxic algal blooms can also have detrimental impacts, and conditions can be improved with management action.

\subsubsection{Mid-Atlantic coastal bays: HABs increase in the past decade}

An analysis of changes in problem occurrences of chlorophyll $a$ and HABs in the mid-Atlantic region, the only region where data were adequate to do the comparison, showed that both have increased. There was a $13 \%$ increase in the number of systems with 'moderate' to 'high' impact of HABs and a $14 \%$ increase in the number of systems with chlorophyll $a$ at 'moderate' to 'high' levels during the past decade, concurrent with increases in nutrient loads (e.g. Kemp et al., 2005; Glibert et al., 2007). In particular, the interest here is in problem occurrences of chlorophyll $a$ and HABs in the mid-Atlantic region lagoons, systems with long residence times.

Five lagoon systems (i.e. water bodies bounded on the ocean side by barrier islands with low freshwater input and small exchange with oceanic waters) in the mid-Atlantic region are included in this analysis; Barnegat Bay, New Jersey Inland Bays, Delaware Inland Bays, Northern Maryland Coastal Bays and Southern Maryland Coastal Bays. The analysis detailed in the section above is of particular relevance in these systems given that they all fall within the slowest residence time group (i.e. very slow in Fig. 8a-c) and thus would be expected to have occurrences of HABs and/or excessive algal blooms. In fact, all but one of these systems have 'moderate' to 'high' levels of chlorophyll $a$ impacts (Fig. 9). All have 'moderate' to 'high' levels of macroalgae, considered a HAB here since Enteromorpha and Ulva are known to smother submerged aquatic vegetation (Dennison et al., 1989), can cause low dissolved oxygen events, and may also smother bivalves (Bricelj and Lonsdale, 1997). Chlorophyll $a$ impacts in
Southern Maryland Coastal Bays, with concentrations reaching $>60 \mu \mathrm{g}^{-1}$ in some locations (Wazniak et al., 2007), and macroalgal impacts in New Jersey Inland and Northern Maryland Coastal Bays have worsened in the decade since the early 1990s (Fig. 9). It is noteworthy that there are only low level impacts of dissolved oxygen depletion in all of these systems. This is likely a result of their characteristically shallow nature (average depth $<2 \mathrm{~m}$ ) that allows for wind mixing or that most measurements are made at midday and do not account for diel oxygen sags.

Although all five have some level of HAB impacts, highest level impacts are observed in Barnegat Bay and the Southern Maryland Coastal Bays (Fig. 9). In Barnegat Bay, HABs have been at a high level for over a decade, while in the Southern Maryland Coastal Bays, data shows that these blooms have become worse during the past decade (Bricker et al., 2007). In fact, in the 1999 assessment (Bricker et al., 1999) the rating for HABs was 'no problem'. In both systems, several toxic and non-toxic HAB species have been observed (Olsen and Mahoney, 2001; Tango et al., 2005) but the most noted HAB is Aureococcus anaphagefferens (Kennish et al., 2007; Olsen and Mahoney, 2001; Glibert et al., 2001; Trice et al., 2004; Glibert et al., 2007), with blooms commonly occurring at category 3 levels ( $>200,000$ cells/L), concentrations which may cause severe impacts on mortality of shellfish and reductions in submerged aquatic vegetation (Gastrich and Wazniak, 2002; Trice et al., 2004). There is also evidence that the frequency, duration and intensity of these blooms has increased in the past decade in the Southern Maryland Coastal Bays (Trice et al., 2004). Annual bloom events have been recorded in Barnegat Bay since 1995 with some recent bloom concentrations reaching $10^{6}$ cells $^{-1}$ (Kennish et al., 2007; Olsen and Mahoney, 2001).

Although troubling, these increases are consistent with observed population increases in coastal watersheds. From 1980 to 2000, population has doubled in the Southern Maryland Coastal Bay watershed (Wazniak et al., 2007) and has increased more than $40 \%$ in the Barnegat Bay watershed (Kennish et al., 2007). Nutrient loads have also increased, with measured DON concentrations doubling in the Southern Maryland Coastal Bays (Glibert et al., 2007). This highlights that the composition of nutrients, in addition to the amounts, entering a system are important factors

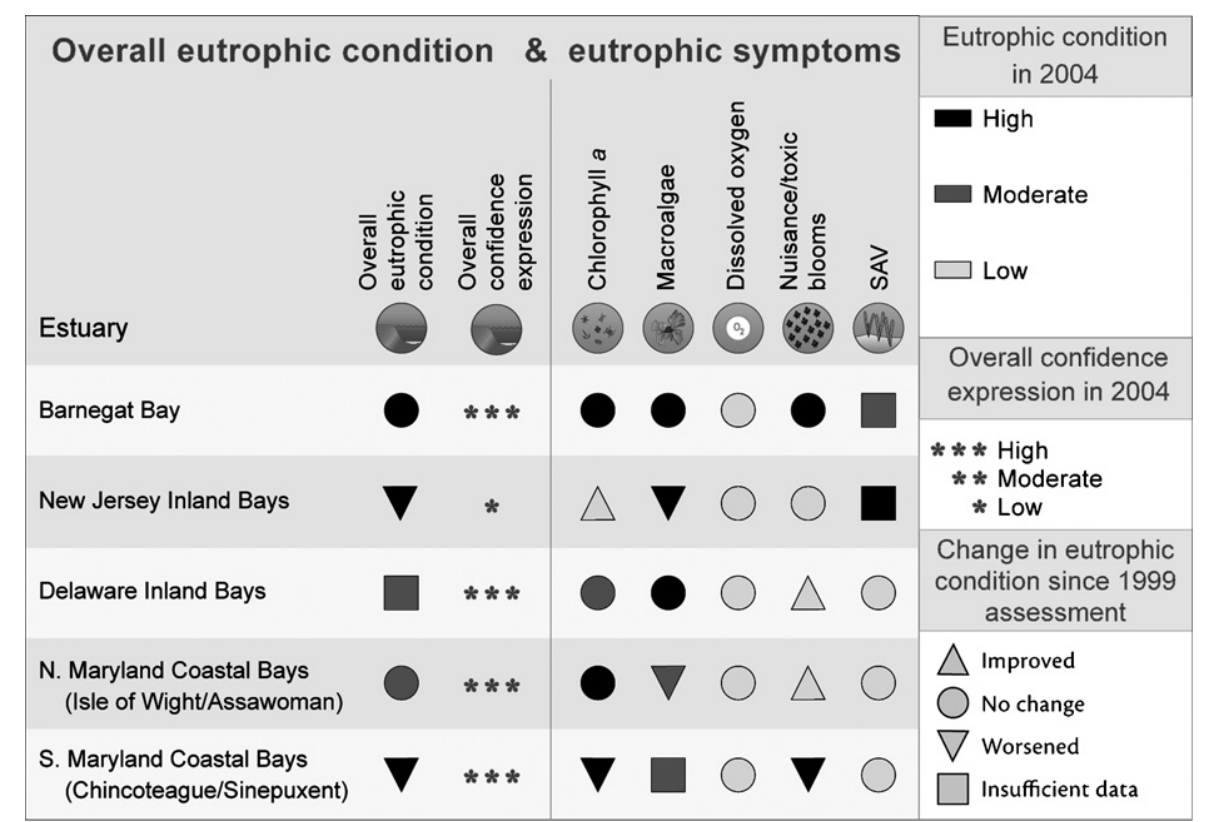

Fig. 9. NEEA results for mid-Atlantic lagoon systems for overall eutrophic condition, overall eutrophic condition confidence rating, and symptom expressions for chlorophyll $a$, macroalgae, dissolved oxygen, nuisance/toxic blooms (HABs) and SAV (adapted from Bricker et al., 2007). 
influencing the species that are able to grow and bloom and suggests that management measures must be attentive to the form and abundance of nutrient that is being targeted for reduction.

\subsubsection{Tampa Bay: Seagrass recovery due to nitrogen load and chlorophyll a reductions}

In Tampa Bay, Florida between 1950 and the early 1980s submerged aquatic vegetation acreage decreased by half; the result of inadequate light to maintain SAV growth (Greening and Janicki, 2006; Dixon, 1999). While toxic HABs do occur, they do not affect submerged aquatic vegetation. Instead, the primary cause of loss was determined to be excess nitrogen loading which resulted in increased algae concentrations leading to reduced light availability for shallow water submerged aquatic vegetation. Actions were taken starting in 1980 to reduce nitrogen inputs to promote regrowth of submerged aquatic vegetation. All municipal wastewater treatment plants were required to provide Advanced Wastewater Treatment for discharges directly to the bay and its tributaries, reducing nitrogen loads from this source by $90 \%$. Stormwater regulations enacted in the 1980 s also contributed to reduced nitrogen loads to the bay. And, the phosphate industry initiated a number of Best Management Practices to reduce nitrogen and phosphorus loads resulting from fertilizer spills from port facilities from which fertilizer products are shipped.

The combined management actions resulted in a significant reduction (60\%) in estimated nitrogen loading from 1985 to 2003 (Greening and Janicki, 2006). Trends in water column chlorophyll $a$ concentrations in Tampa Bay show similar patterns: excessive levels decreased significantly in the mid-1980s, followed by fluctuations in recent years. Submerged aquatic vegetation extent showed a similar response with an increased spatial coverage and the greatest acreage since 1950 observed in 2004. Fluctuations in chlorophyll $a$ and submerged aquatic vegetation coverage since about 1990 appear to be associated with rainfall amounts, with high rainfall events associated with higher nutrient load delivery to Tampa Bay with resultant decrease in water clarity and submerged aquatic vegetation acreage (Tomasko et al., 2005). In this system, the potential decrease in residence time as a result of higher waterflow is counterbalanced by the nutrient loads which in this system are dominated by stormwater runoff. Comparison of this system with the slow residence time systems of the midAtlantic, which benefit from high rainfall events that increase waterflow through the lagoons, confirms that resource management strategies must take into account system specific factors.

\section{Conclusions and recommendations}

The finding that nearly two-thirds of the US estuaries that were assessed have moderate to high level expression of eutrophication is of considerable importance. Eutrophic symptoms cause impairments to human uses and to living resources including fish kills, fish consumption warnings (to prevent human health problems), and declines in tourism. While these results show that conditions have not changed much in the past decade, the expected $12 \%$ average increase in national coastal population (already $53 \%$ of total) by the year 2020 with larger increases expected locally (Crossett et al., 2004), suggests that managing against future worsening conditions will be more and more difficult. Reducing eutrophic conditions in estuaries in light of these expectations requires coordinated and integrated action that balances management action, efficient monitoring to assess the effectiveness of the management, targeted research, and a communication campaign aimed at engaging the broader community. Because these impacts are observed in systems along all coastlines, management, monitoring, and research actions are needed at local, regional and national scales. Typically management must be done on a local scale, however, monitoring and research can be done on variable scales, with national monitoring results, as an example, providing insight to regional patterns (e.g. of forcing functions) that may provide the basis for more successful management at the local scale. The results of this study call for these major recommendations:

Management: Aggressive management actions, both traditional and alternative/innovative, should continue to be implemented in order to achieve nutrient reductions to reduce widespread eutrophic conditions.

Monitoring: The number of systems with inadequate data for evaluation suggests that a national comprehensive monitoring program is needed to capitalize on technology (e.g. observing systems, remote sensing) and to provide rigorous, easily accessible, nationally comparable data (both in situ and remotely sensed) for tracking trends.

Research: Research should focus on improving monitoring and assessment of eutrophication, resolving uncertainties, and establishing criteria and thresholds in order to elucidate potential, and evaluate current management options.

Communication: Resource managers, researchers, policy makers, and the community should be engaged with frequent assessment updates including environmental report cards (e.g. http://www.eco-check.org/reportcard/chesapeake/2007/),

illustrative graphics and maps, and involvement in hands on restoration efforts to foster interest, inform, and empower support of critical management actions.

\section{Acknowledgements}

The authors are grateful for contributions of data, information, and expertise provided by national and international estuarine research scientists and coastal resource managers who participated in the NEEA and were critical to making this work possible. We thank Holly Greening for data and information about Tampa Bay. We also than Pat Glibert and an anonymous reviewer whose comments greatly improved the manuscript.[SS]

\section{References}

Anderson, D.M., Glibert, P.M., Burkholder, J.M., 2002. Harmful algal blooms and eutrophication: Nutrient sources, composition, and consequences. Estuaries 25, 704-726.

Bowen, J.L., Valiela, I., 2001. The ecological effects of urbanization of coastal watersheds: Historical increases in nitrogen loads and eutrophication of Waquoit Bay estuaries. Canadian Journal of Fisheries and Aquatic Sciences 58, 1489-1500.

Breitburg, D., 2002. Effects of hypoxia, and the balance between hypoxia and enrichment, on coastal fishes and fisheries. Estuaries 25, 767-781.

Bricelj, V.M., Lonsdale, D.J., 1997. Aureococcus anophagefferens: causes and ecological consequences of browntides in US mid-Atlantic coastal waters. Limnology Oceanography 42, 1023-1038.

Bricker, S., Longstaff, B., Dennison, W., Jones, A., Boicourt, K., Wicks, C., Woerner, J., 2007. Effects of Nutrient Enrichment in the Nation's Estuaries: A Decade of Change, National Estuarine Eutrophication Assessment Update. NOAA Coastal Ocean Program Decision Analysis Series No. 26. National Centers for Coastal Ocean Science, Silver Spring, MD.

Bricker, S.B., Clement, C.G., Pirhalla, D.E., Orlando, S.P., Farrow, D.R.G., 1999. National Estuarine Eutrophication Assessment: Effects of Nutrient Enrichment in the Nation's Estuaries. NOAA, National Ocean Service, Special Projects Office and the National Centers for Coastal Ocean Science. Silver Spring, MD.

Bricker, S.B., Ferreira, J.G., Simas, T., 2003. An Integrated Methodology for Assessment of Estuarine Trophic Status. Ecological Modelling 169, 39-60.

Bricker, S., Lipton, D., Mason, A., Dionne, M., Keeley, D., Krahforst, C., Latimer, J., Pennock, J., 2006. Improving Methods and Indicators for Evaluating Coastal Water Eutrophication: A Pilot Study in the Gulf of Maine. NOAA Technical Memorandum NOS NCCOS 20. National Ocean Service, National Centers for Coastal Ocean Science, Center for Coastal Monitoring and Assessment, Silver Spring, MD. 
Castro, M., Driscoll, C.T., Jordan, T.E., Reay, W.G., Boynton, W.R., Seitzinger, S.P. Styles, R.V., Cable, J.E., 2001. Contribution of atmospheric deposition to the total nitrogen loads to thirty four estuaries on the Atlantic and Gulf Coasts of the United States. In: Valigura, R.A., Alexander, R.B., Castro, M.S., Meyers, T.P. Paerl, H.W., Stacey, P.E., Turner, R.E. (Eds.), Nitrogen Loading in Coastal Water Bodies: An Atmospheric Perpective Coastal and Estuarine Studies. American Geophysical Union, Washington, DC, pp. 77-106.

Committee on Environmental and Natural Resources (CENR), 2000. Integrated assessment of hypoxia in the northern Gulf of Mexico. National Science and Technology Council Committee on Environment and Natural Resources, Washington, DC, 58 pp.

Crossett, K.M., Culliton, T.J., Wiley, P.C., Goodspeed, T.R., 2004. Population Trends along the coastal United States: 1980-2008. National Oceanic and Atmospheric Administration, National Ocean Service, Management and Budget Office, Special Projects.

Dennison, W.C., Marshall, G.J., Wigand, C., 1989. Effect of "brown tide" shading on eelgrass (Zostera marina L.) distributions. In: Cosper, E., Bricelj, V.J., Carpenter E.J. (Eds.), Novel Phytoplankton Blooms: Causes and Impacts of Recurrent Brown Tides and Other Unusual blooms. Lecture Notes on Coastal and Estuarine Studies. Springer-Verlag, New York, USA, pp. 675-692.

Dixon, L.K., 1999. Establishing light requirements for the seagrass Talassia testudinum: An example for Tampa Bay, Florida. In: Bortone, S.A. (Ed.), Seagrasses: Monitoring, Ecology Physiology and Management. CRC Press, Boca Raton, Florida, pp. 9-31.

Ferreira, J.G., Wolff, W.J., Simas, T.C., Bricker, S.B., 2005. Does biodiversity of estuarine phytoplankton depend on hydrology? Ecological Modelling 187, 513-523.

Ferreira, J.G., Bricker, S.B., Simas, T.C., 2007. Application and sensitivity testing of an eutrophication assessment method on coastal systems in the United States and European Union. Journal of Environmental Management 82 (4) 433-445.

Furnas, M.J., 1990. In situ growth rates of marine phytoplankton: approaches to measurement, community and species growth rates. Journal of Plankton Research 12, 1117-1151.

Gastrich, M., Wazniak, C.E., 2002. A brown tide bloom index based on the potential harmful effects of the brown tide alga Aureococcus anophagefferens. Aquatic and Ecosystem Health Management 5, 435-441.

Glibert, P.M., Magnien, R., Lomas, M.W., Alexander, J., Fan, C., Haramoto, E., Trice, M., Kana, T.M., 2001. Harmful algal blooms in the Chesapeake and Coastal Bays of Maryland, USA: Comparison of 19971998 and 1999 events. Estuaries 24 (6a), 875-883.

Glibert, P.M., Anderson, D.A., Gentien, P., Granéli, E., Sellner, K.G., 2005a. The global, complex phenomena of harmful algal blooms. Oceanography 18 (2), 136-147.

Glibert, P.M., Seitzinger, S., Heil, C.A., Burkholder, H.M., Parrow, M.W., Codispoti, L.A., Kelly, V., 2005b. The role of eutrophication in the global proliferation of Harmful Algal Blooms. Oceanography 18 (2), 198-209.

Glibert, P.M., Wazniak, C.E., Hall, M.R., Sturgis, B., 2007. Seasonal and interannual trends in nitrogen and brown tide in Maryland's coastal bays. Ecological Applications 17 (Special Issue), S79-S87.

Greening, H., Janicki, A., 2006. Toward reversal of eutrophic conditions in a subtropical estuary: Water quality and seagrass response to nitrogen loading reductions in Tampa Bay, Florida USA. Environmental Management 38 (2), $163-178$.

Heisler, J., Glibert, P., Burkholder, J., Anderson, D., Cochlan, W., Dennison, W., Gobler, C. Dortch, Q. Heil, C., Humphries, E, Lewitus, A., Magnien, R., Marshall, $H$. Sellner, K., Stockwell, D., Stoecker, D., Suddleson, M., 2008. Eutrophication and Harmful Algal Blooms: A Scientific Consensus. Harmful Algae 8, 3-13.

Hoagland, P., Anderson, D.M., Kaoru, Y., White, A.W., 2002. The economic effects of harmful algal blooms in the United States: Estimates, assessment issues and information needs. Estuaries 25 (4b), 819-837.
Kemp, W.M., Boynton, W.R., Adolf, J.E., Boesch, D.F., Boicourt, W.C., Brush, G., Cornwell, J.C., Fisher, T.R., Glibert, P.M., Hagy, J.D., Harding, L.W., Houde, E.D. Kimmel, D.G., Miller, W.D., Newell, R.I.E., Roman, M.R., Smith, E.M., Stevenson, J.C., 2005. Eutrophication of Chesapeake Bay: historical trends and ecological interactions. Marine Ecology Progress Series 303, 1-29.

Kennish, M.J., Bricker, S.B., Dennison, W.C., Glibert, P.M., Livingston, R.J., Moore, K.A. Noble, R.T., Paerl, H.W., Ramstack, J., Seitzinger, S., Tomasko, D.A., Valiela, I., 2007. Barnegat Bay-Little Egg Harbor Estuary: Case Study of a Highly Eutrophic Coastal Bay System. Ecological Applications 17 (Special Issue), S3-S16.

Lipton, D.W., Hicks, R., 1999. Linking water quality improvements to recreational fishing values: The case of Chesapeake Bay striped bass. In: Evaluating the Benefits of Recreational Fisheries. Fisheries Centre Research Reports 7(2). University of British Columbia.

Lipton, D.W., Hicks, R., 2003. The cost of stress: Low dissolved oxygen and recreational striped bass (Morone saxatilis) fishing in the Patuxent River. Estuaries 26 , 310-315.

Magnien, R., 2001. The dynamics of science, perception and policty during the outbreak ofPfiesteriain the Chesapeake Bay. Bioscience 51, 843-852.

National Research Council (NRC), 2000. Clean Coastal Waters: Understanding and reducing the effects of Nutrient Pollution. National Academy Press, Washington, DC.

Nobre, A.M., Ferreira, J.G., Newton, A., Simas, T., Icely, J.D., Neves, R., 2005. Managing eutrophication: Integration of field data, ecosystem-scale simulations and screening models. Journal of Marine Systems 56, 375-390.

Scavia, D., Bricker, S.B., 2006. Coastal eutrophication assessment in the United States. Biogeochemistry $79(1-2), 187-208$

Smayda, T.J., 1997. Harmful algal blooms: their ecophysiology and general relevance to phytoplankton blooms in the sea. Limnology and Oceanography 42 , $1137-1153$

Olsen, P.S., Mahoney, J.B., 2001. Phytoplankton in the Barnegat Bay-Little Egg Harbor estuarine system: Species composition and picoplankton bloom development. Journal of Coastal Research SI32, 115-143.

Tango, P., Butler, W., Wazniak, C., 2005. Assessment of harmful algal blooms in the Maryland coastal bays. In: Wazniak, C., Hall, M. (Eds.), Maryland's Coastal bays Ecosystem Health Assessment 2004. DNR-12-12-2-0009. Maryland Department of Natural Resources Tidewater Ecosystem Assessment. Annapolis, Maryland, USA, pp. 8-2-8-32.

Tomasko, D.A., Corbett, C.A., Greening, H.S., Raulerson, G.E., 2005. Spatial and temporal variations in seagrass coverage in Southwest Florida: Assessing the relative effects of anthropogenic nutrient load reductions and rainfall in four contiguous estuaries. Marine Pollution Bulletin 50, 797-805.

Tomasko, D.A., Dawes, C.J., Hall, M.O., 1996. The effects of anthropogenic nutrient enrichment on turtle grass (Thalassia testudinum) in Sarasota Bay Florida. Estuaries 19, 448-456.

Trice, T.M., Glibert, P.M., Lea, C., Van Heukelem, L., 2004. HPLC pigment records provide evidence of past blooms ofAureoccocus anophagefferensin the coastal bays of Maryland and Virginia USA. Harmful Algae 3, 295-304.

United States Environmental Protection Agency (USEPA), 2005. National Coastal Condition Report II. Office of Research and Development, Office of Water Washington, DC. EPA-620/R-03/002.

Wazniak, C.E., Hall, M.R., Carruthers, T.B., Sturgis, B., Dennison, W.C., Orth, R.J., 2007. Linking water quality to living resources in a mid-Atlantic lagoon system USA. Ecological Applications 17, S64-S78.

Wazniak, C.E., Glibert, P.M., 2004. Potential impacts of brown tide, Aureococcus anophagefferens, on juvenile hard clams, Mercenaria mercenaria, in the coastal bays of Maryland USA. Harmful Algae 3, 321-329.

Xiao, Y., Ferreira, J.G., Bricker, S.B., Nunes, J.P., Mingyuan, Z., Zhang, X., 2007. Trophic assessment in Chinese coastal systems-Review of methodologies and application to the Changjiang (Yangtze) Estuary and Jiaozhou Bay. Estuaries and Coasts 30, 901-918. 